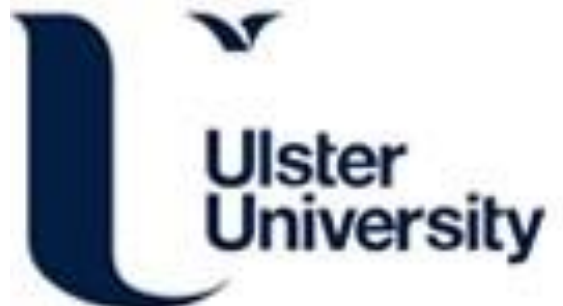

\section{Retreat of the Antarctic Ice Sheet During the Last Interglaciation and Implications for Future Change}

Golledge, N. R., Clark, P. U., He, F., Dutton, A., Turney, C. S. M., Fogwill, C. J., Naish, T. R., Levy, R. H.,

McKay, R. M., Lowry, D. P., Bertler, N. A. N., Dunbar, G. B., \& Carlson, A. E. (2021). Retreat of the Antarctic Ice Sheet During the Last Interglaciation and Implications for Future Change. Geophysical Research Letters, 48(17). https://doi.org/10.1029/2021gl094513

Link to publication record in Ulster University Research Portal

\section{Published in:}

Geophysical Research Letters

Publication Status:

Published (in print/issue): 08/09/2021

DOI:

10.1029/2021gl094513

\section{Document Version}

Publisher's PDF, also known as Version of record

\section{General rights}

Copyright for the publications made accessible via Ulster University's Research Portal is retained by the author(s) and / or other copyright owners and it is a condition of accessing these publications that users recognise and abide by the legal requirements associated with these rights.

\section{Take down policy}

The Research Portal is Ulster University's institutional repository that provides access to Ulster's research outputs. Every effort has been made to ensure that content in the Research Portal does not infringe any person's rights, or applicable UK laws. If you discover content in the Research Portal that you believe breaches copyright or violates any law, please contact pure-support@ulster.ac.uk. 


\section{Geophysical Research Letters}

\author{
RESEARCH LETTER \\ 10.1029/2021GL094513 \\ Key Points: \\ - We present data-constrained \\ simulations of the Antarctic \\ Ice Sheet through the Last \\ Interglaciation \\ - Our model predicts a maximum \\ contribution to global mean sea level \\ of $4 \mathrm{~m}$ at $126 \mathrm{ka}$ BP \\ - Loss of much of the present-day \\ West Antarctic Ice Sheet is already \\ committed under current climate
}

Supporting Information:

Supporting Information may be found in the online version of this article.

Correspondence to:

N. R. Golledge,

nicholas.golledge@vuw.ac.nz

Citation:

Golledge, N. R., Clark, P. U., He, F., Dutton, A., Turney, C. S. M., Fogwill, C. J., et al. (2021). Retreat of the Antarctic Ice Sheet during the Last Interglaciation and implications for future change. Geophysical Research Letters, 48, e2021GL094513. https://doi. org/10.1029/2021GL094513

Received 25 MAY 2021

Accepted 5 AUG 2021

(C) 2021. American Geophysical Union. All Rights Reserved.

\section{Retreat of the Antarctic Ice Sheet During the Last Interglaciation and Implications for Future Change}

\author{
N. R. Golledge ${ }^{1}$ (D) P. U. Clark ${ }^{2,3}$, F. He ${ }^{4}$, A. Dutton ${ }^{5}$ (D, C. S. M. Turney ${ }^{6,7,8}$ (D) \\ C. J. Fogwill ${ }^{6,9,10}$ (D) T. R. Naish ${ }^{1}$, R. H. Levy ${ }^{1,11}$ (D) R. M. McKay ${ }^{1}$ (D) D. P. Lowry ${ }^{11}$, \\ N. A. N. Bertler ${ }^{1,11}$, G. B. Dunbar ${ }^{1}$, and A. E. Carlson ${ }^{12}$
}

${ }^{1}$ Antarctic Research Centre, Victoria University of Wellington, Wellington, New Zealand, ${ }^{2}$ College of Earth, Ocean, and Atmospheric Sciences, Oregon State University, Corvallis, OR, USA, ${ }^{3}$ School of Geography and Environmental Sciences, University of Ulster, Coleraine, UK, ${ }^{4}$ Center for Climatic Research, Nelson Institute for Environmental Studies, University of Wisconsin-Madison, Madison, WI, USA, ${ }^{5}$ Department of Geoscience, University of Wisconsin-Madison, Madison, WI, USA, ${ }^{6}$ School of Biological, Earth and Environmental Sciences, Earth and Sustainability Science Research Centre, University of New South Wales, Kensington, NSW, Australia, ${ }^{7}$ School of Biological, Earth and Environmental Sciences, Australian Research Council Centre of Excellence in Australian Biodiversity and Heritage, University of New South Wales, Kensington, NSW, Australia, ${ }^{8}$ Chronos 14 Carbon-Cycle Facility, University of New South Wales, Sydney, NSW, Australia, ${ }^{9}$ School of Geography, Geology and the Environment, Keele University, Staffordshire, UK, ${ }^{10}$ School of Water, Energy and the Environment, Cranfield University, Cranfield, UK, ${ }^{11}$ GNS Science, Lower Hutt, New Zealand, ${ }^{12}$ Oregon Glaciers Institute, Corvallis, OR, USA

Abstract The Antarctic Ice Sheet (AIS) response to past warming consistent with the $1.5-2^{\circ} \mathrm{C}$ "safe limit" of the United Nations Paris Agreement is currently not well known. Empirical evidence from the most recent comparable period, the Last Interglaciation, is sparse, and transient ice-sheet experiments are few and inconsistent. Here, we present new, transient, GCM-forced ice-sheet simulations validated against proxy reconstructions. This is the first time such an evaluation has been attempted. Our empirically constrained simulations indicate that the AIS contributed $4 \mathrm{~m}$ to global mean sea level by $126 \mathrm{ka} \mathrm{BP}$, with ice lost primarily from the Amundsen, but not Ross or Weddell Sea, sectors. We resolve the conflict between previous work and show that the AIS thinned in the Wilkes Subglacial Basin but did not retreat. We also find that the West AIS may be predisposed to future collapse even in the absence of further environmental change, consistent with previous studies.

Plain Language Summary Ice sheets can respond to climatic warming in complex ways, commonly only reaching a new state of balance many hundreds or even thousands of years after the initial change in climate has occurred. Here, we investigate how the Antarctic Ice Sheet (AIS) responded to a period of prolonged warmer-than-present climate that took place around 125,000 years ago. At this time the global climate was only around $1-2^{\circ} \mathrm{C}$ above present, but geological records show that the global sea level was at least $6 \mathrm{~m}$, or maybe even as much as 9-11 m, higher than today. Our study shows that around $4 \mathrm{~m}$ of this could have come from Antarctica. Our model agrees well with geological evidence of enhanced ice discharge both close to the ice sheet and further afield. Applying this model to the future our experiments suggest that the West AIS may already have been sufficiently destabilized to trigger a longterm sea-level contribution of up to $4 \mathrm{~m}$, even without further greenhouse gas emissions.

\section{Introduction}

Evidence of ice sheet changes during the last time when global mean sea level (GMSL) was above present is sparse. This period, the Last Interglaciation (LIG; 129-116 ka BP) was most likely characterized by a highstand in GMSL of 6-9 m (Dutton et al., 2015; Masson-Delmotte et al., 2013) or higher (Rohling et al., 2019), but global mean surface temperatures (GMSTs) only slightly elevated (ca. $+0.5-1.0^{\circ} \mathrm{C}$ ) with respect to early industrial times (late 19th century; Hoffman et al., 2017; Fischer et al., 2018; Masson-Delmotte et al., 2013; Turney, Jones, et al., 2020). GMST was amplified in the polar regions, with Arctic surface temperature anomalies of $>3-11^{\circ} \mathrm{C}$, substantially above the global mean (Fischer et al., 2018; Landais et al., 2016; Yau et al., 2016). Global mean ocean temperatures reached their maximum early in the LIG (129-127 ka BP) reaching $1.1 \pm 0.3^{\circ} \mathrm{C}$ above modern (approximately $2^{\circ} \mathrm{C}$ above early industrial; Shackleton et al., 2020). Around Antarctica, ocean temperatures reached their maxima ca. 129-127 ka BP in the Atlantic and Indian 
Ocean sectors, and ca. 125 ka BP in the Pacific sector (Chadwick et al., 2020). Warming of subsurface water relative to glacial maximum conditions exceeded sea surface warming during the LIG, and was most likely a consequence of a prolonged period of relatively weak Atlantic Meridional Overturning Circulation during the penultimate deglaciation (Clark et al., 2020; Marino et al., 2015; Turney, Fogwill, et al., 2020).

Thermal expansion of the ocean early in the LIG, peaking around $129 \mathrm{ka}$, accounts for up to $0.8 \mathrm{~m}$ sea-level-equivalent (SLE) change (Shackleton et al., 2020; Turney, Jones, et al., 2020) and although the timing of their retreat is not known, global glaciers could have contributed a maximum of $0.32 \pm 0.08 \mathrm{~m}$ based on estimates of their current volume (Marzeion et al., 2020). The SLE contribution from the Greenland Ice Sheet (GrIS) is modeled to be anywhere from ca. $0.9 \mathrm{~m}$ (Clark et al., 2020) to ca. $5.1 \mathrm{~m}$ (Yau et al., 2016), with the majority of models and proxy-based reconstructions indicating likely mass loss in the 1-2 m SLE range (Bradley et al., 2018; Calov et al., 2015; Colville et al., 2011; Dahl-Jensen et al., 2013; Goelzer et al., 2016), most likely peaking or reaching peak contributions late in the LIG (post $125 \mathrm{ka}$ ).

The Antarctic Ice Sheet (AIS) has been less well studied, particularly in terms of ice sheet model (ISM) simulations that use ocean-atmosphere boundary conditions directly from general circulation models (GCMs) or regional climate models (RCMs). Whole-continent ISM reconstructions that have used environmental forcings directly from climate models without the ad hoc imposition of additional heat predict an AIS LIG contribution of 3-4.4 m (Clark et al., 2020; Goelzer et al., 2016). Whole continent as well as single catchment or limited area models have been used to investigate the sensitivity of key AIS drainage basins to both realistic and conceptual warming levels (Feldmann \& Levermann, 2015; Golledge, Thomas, et al., 2017; Mengel \& Levermann, 2014; Sutter et al., 2020) but the scarcity of near-field empirical evidence with which to constrain ISM simulations prevents a critical evaluation of either the AIS contribution to LIG GMSL or the robustness of the models themselves.

Proxies that enable model-data comparison include stable isotope records from ice cores, which allow changes in surface temperatures and/or changes in surface elevation to be approximated if assumptions are made regarding past ice flow (Goursaud et al., 2020). Ice core studies can be used with climate model simulations to gauge whether changes in ice sheet geometry may have altered climatic conditions at a core site during periods of the past, such as the LIG (Steig et al., 2015). In addition to isotopic evidence of AIS change during the LIG there also exists a horizontal ice core record from the Patriot Hills (Horseshoe Valley, West Antarctica; Turney, Fogwill, et al., 2020) and marine sediment records from offshore the Wilkes Subglacial Basin (WSB, East Antarctica; Wilson et al., 2018) and the western Antarctic Peninsula (Carlson et al., 2021). The Patriot Hills blue ice record (Turney, Fogwill, et al., 2020) incorporates volcanic glass geochemically correlated with tephra in the Dome Fuji ice core, dated to 130.7 \pm 1.8 ka BP (AICC2012 timescale; Hillenbrand et al., 2008), abruptly truncated by a hiatus in ice accumulation until ca. $80 \mathrm{ka}$ BP. This hiatus is interpreted as evidence of dynamic thinning of this sector of the ice sheet during, and following, the LIG (Turney, Fogwill, et al., 2020). The marine sediment core offshore the WSB at U1361A reveals a clear signal of increased iceberg rafted debris (IBRD) over the site during the LIG, which together with provenance indicators from muds eroded off the continental margin suggests either a retreat of the ice margin in the WSB, or an increase in basal erosion and sediment transport from this area (Wilson et al., 2018). A second marine core, ODP 1096 (Figure 1c), records only sediment sourced from the Antarctic Peninsula during the LIG but deposition of WAIS-derived sediment from $116 \mathrm{ka}$, suggesting perhaps that WAIS had retreated during the interglaciation and subsequently readvanced (Carlson et al., 2021).

No whole-continent AIS simulations have yet been explicitly assessed in terms of their agreement with the suite of proxy indicators of Antarctic ice-sheet changes described above. In this study, we therefore (a) present new ISM simulations for the period 140-116 ka BP, and (b) compare modeled changes with those inferred from ice-proximal and ice-distal proxy reconstructions described above.

\section{Methods}

We use the Parallel Ice Sheet Model (PISM; Bueler \& Brown, 2009; Winkelmann et al., 2010), a fixed-grid thermodynamic ISM that uses a hybrid stress balance combining shallow approximations of the flow equations for grounded and floating ice. PISM incorporates a one-dimensional elastic lithosphere-relaxing asthenosphere solid earth deformation model based on the fast Fourier transform solution of Lingle and 
a

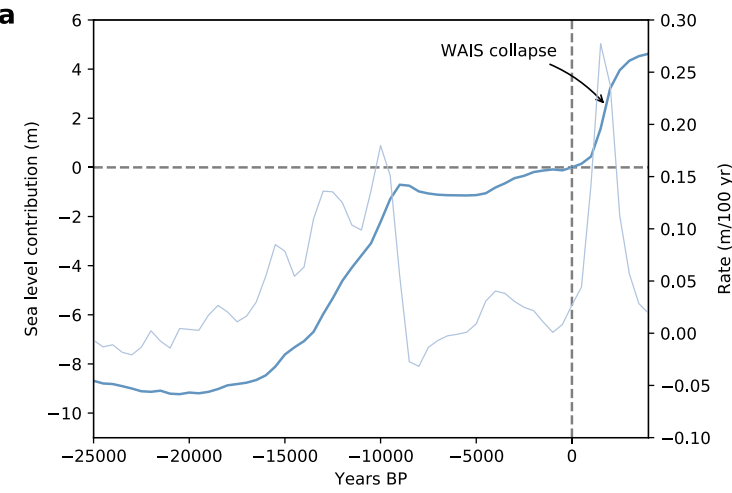

b

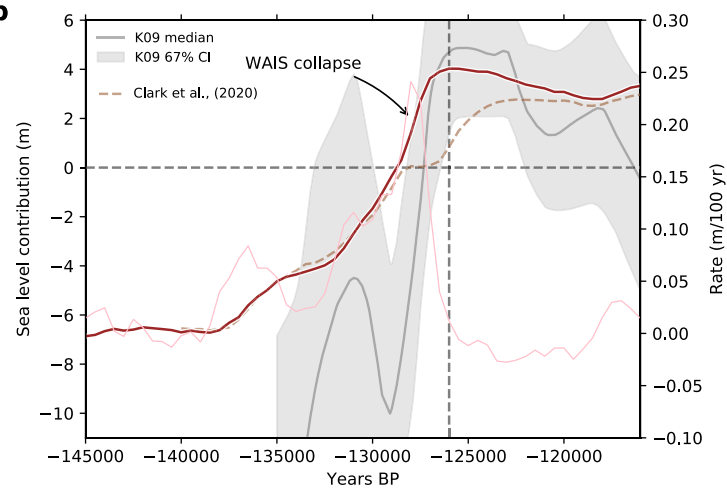

C

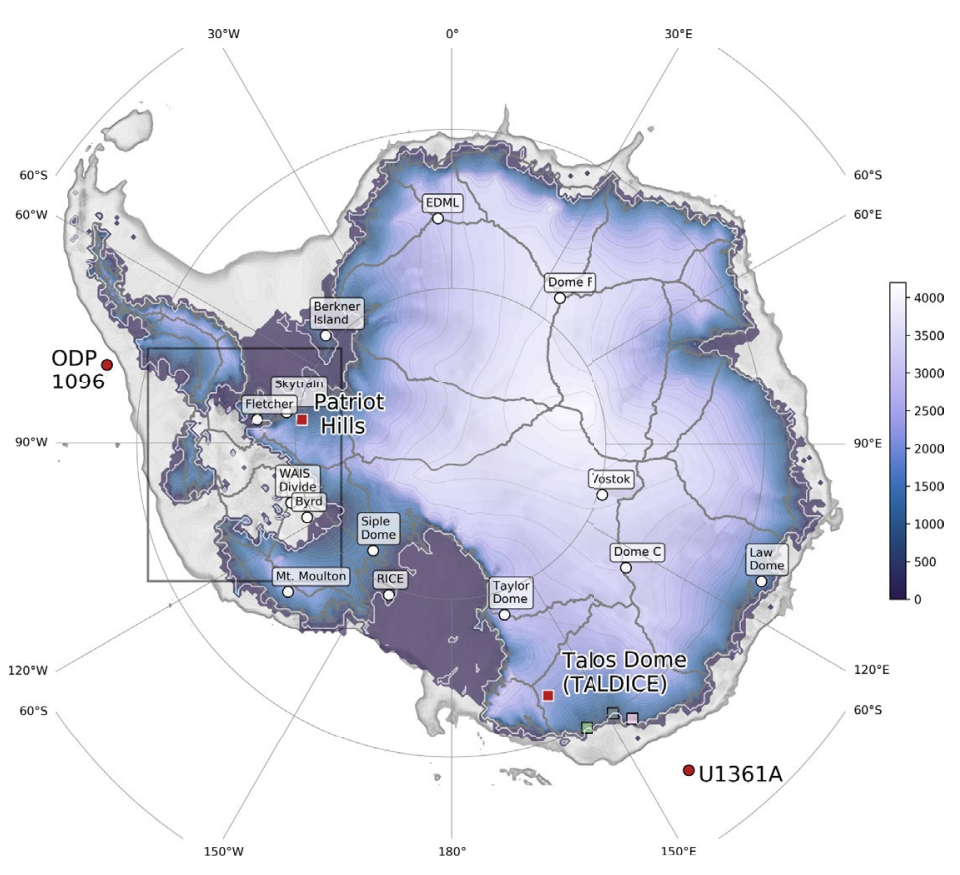

Figure 1. Simulated mass loss from the Antarctic Ice Sheet (AIS; bold lines) during (a) the last and (b) the penultimate glacial terminations. Rates-of-change shown with thinner lines in each panel. Modeled LIG SLE mass loss from Clark et al. (2020) shown with dashed brown line in (b) for comparison to the new simulation. Median and 67\% confidence interval of a probabilistic reconstruction of the Southern Hemisphere contribution to global mean sea level shown with gray line and shading (Kopp et al., 2009). (c) Surface elevation (meters) of the modeled AIS at $126 \mathrm{ka}$ BP when peak LIG mass loss is reached. Patriot Hills blue ice area, Talos Dome ice core site, ODP1096 and U1361A marine sediment core locations, and the three sites (colored boxes) investigated in Figure 4 are also shown. Labeled white squares identify other ice core locations for which predictions of ice sheet change are presented in Figure S6. Gray lines show the presentday boundaries of grounded ice catchments (Zwally et al., 2012). Black rectangle denotes the area shown in Figure 2.

Clark (1985) and Bueler et al. (2007), allowing us to capture the multi-millennial effects of ice loading on bedrock elevation. To ensure comparability of results with previous work, our simulations use the exact same parameterizations employed in Clark et al. (2020) except for modifications to mantle viscosity and bed elevation, as described in detail below. The optimal parameter set (Table S1) was chosen based on how well it allowed the last glacial maximum and present-day extents to be captured. Using a manual tuning procedure we explored the sensitivity of the model to changes in flow enhancement factors, basal substrate rheology and sliding parameters, different grounding line schemes, and calving approximations. We ran 103 transiently forced simulations of 40-50 kyr duration each. The time evolution of grounded ice volume for these ensemble members is shown in Figure S1.

We implement the model at $20 \mathrm{~km}$ horizontal resolution and make use of the native subgrid grounding-line scheme to improve the sensitivity of this coarse grid simulation to oceanic forcing. Using spatially explicit, time varying, oceanic and atmospheric anomalies (compared to present-day) from the National Center for Atmospheric Research Community Climate System Model version 3 (NCAR CCSM3; Clark et al., 2020) we run duplicate simulations for Termination 1 (T1; 20-0 ka BP) and Termination 2 (T2; 140-116 ka BP). We follow the exact same procedure as in Clark et al. (2020) and use simulations of the last glacial termination (T1) to ensure that our model can reproduce the extended glacial maximum configuration and present-day ice extent. Simulations for the penultimate glacial termination (T2) and LIG are then run with the climate forcing (ocean temperature and salinity, air temperature, precipitation, global mean sea level) from CCSM3. A novel component of the new study presented here is that we also extend our T1 simulation for an additional 4 kyr, holding present-day (1979-2010) basal melt rates (Bernales et al., 2017) and atmospheric forcing (Golledge et al., 2019) fixed, to investigate the future dynamic (not climate-forced) response of the AIS. 
Slow build-up of ice over the approximately $100 \mathrm{ka}$ before both of the last two glacial terminations would have led to a bedrock elevation that was in equilibrium with the increased glacial maximum ice load above. To ensure that our simulations accurately reproduce this state before the start of the transient deglacial simulations we precede each of these simulations with a $20 \mathrm{kyr}$ period during which a constant "glacial maximum" climate field is applied. The conditions imposed during this phase are taken as the glacial maxima represented in the CCSM3 simulations at 140 and $20 \mathrm{ka}$ BP for T2 and T1, respectively. Compared to Clark et al. (2020) our new simulations use an upper mantle viscosity value that is increased from $1.0 \times 10^{19} \mathrm{~Pa} \mathrm{~s}$ to $1.3 \times 10^{20} \mathrm{~Pa}$ s, as well as a topographic elevation correction to account for the effect of dynamic topography (Austermann et al., 2015; Figure S2). These modifications are implemented in an attempt to determine whether a better fit to the timing of AIS changes interpreted from the two key Antarctic glaciological and geological records described above (Turney, Fogwill, et al., 2020; Wilson et al., 2018) could be produced, compared to that in our original simulations (Clark et al., 2020). The dynamic topography correction accounts for at most an approximately $10 \mathrm{~m}$ lower bed in the Wilkes Subglacial Basin region (Figure S2), whereas the changes to mantle rheology are more significant. We justify our imposed modification on the following grounds. In PISM v0.7.1 the one-dimensional Earth deformation model uses a single upper mantle viscosity value for the whole domain. Our previous choice of $1.0 \times 10^{19} \mathrm{~Pa}$ s is representative of inferences for West Antarctica from a range of studies (Table S2). However, considerable uncertainty exists, both in terms of vertical and horizontal heterogeneity, and values at or above $1 \times 10^{20} \mathrm{~Pa}$ s have also been reported for West Antarctica and the Antarctic Peninsula (Bradley et al., 2015; Ivins et al., 2021; Nield et al., 2016; Pan et al., 2021; Samrat et al., 2020; Wolstencroft et al., 2015). Thus, whilst West Antarctic upper mantle viscosity is considered to be low by Antarctic standards, our modified value is within the range of current estimates. Other published LIG ice sheet simulations (DeConto \& Pollard, 2016; Goelzer et al., 2016) have both used a radially symmetric one-dimensional isostatic scheme from Huybrechts and de Wolde (1999), but that scheme "produces results close to those from a full visco-elastic treatment with mantle viscosities in the range $0.5-1.0 \times 10^{21} \mathrm{~Pa} \mathrm{~s}$ " (Huybrechts, 2002), essentially 4- 8 times stiffer than our parameterization. In our simulations, iterative experimentation showed that only a narrow range of mantle viscosity values exists that allow present-day grounding lines to be matched whilst also yielding above-present LIG mass loss (Figures S3 and S4) inferred from other studies (Figure 1b; Kopp et al., 2009).

\section{Results}

Figure 1 illustrates the AIS response in terms of SLE mass loss to deglacial environmental forcings for (a) $\mathrm{T} 1$ and (b) T2. SLE is calculated as the domain-integrated ice thickness above flotation compared to our modeled present-day geometry. Our frame-by-frame calculation captures temporal changes both in bedrock elevation and in ice thickness. Based on this approach, mass loss above present is first achieved shortly after $129 \mathrm{ka}$, peaking at $126 \mathrm{ka}$ with a sea-level contribution of $4.03 \mathrm{~m}$. This ice volume minimum is maintained only briefly followed by a slow regrowth of the ice sheet and lowering of sea level to $118 \mathrm{ka}$, followed by renewed mass loss that continues to the end of the simulation at $116 \mathrm{ka}$. Both the timing and magnitude of peak modeled AIS mass loss are consistent with probabilistic estimates (Kopp et al., 2009) of the Southern Hemisphere sea-level contribution during this period (Figure 1b, gray line and shading) but our modeled sea-level contribution starts to exceed present-day sea level around 2,000 years earlier than the Kopp et al. (2009) median. Comparison of isotopic changes in the Mt Moulton ice core (Steig et al., 2015) with climate model simulations has been used to infer little or no mass loss (relative to present) from the WAIS before $128 \mathrm{ka} \mathrm{BP}$ and maximum WAIS retreat by $126 \mathrm{ka}$ (Holloway et al., 2016), which our simulation is also largely consistent with. The AIS contribution to LIG GMSL in our simulation is spatially heterogenous but comes primarily from the Thwaites and Pine Island Glacier catchments of the WAIS (Figure 1c). As a consequence of CCSM3-simulated cooler-than-present subsurface ocean temperatures in the Ross and Weddell seas (Figure S5), both the Ross and Filchner-Ronne ice shelves remain intact. In East Antarctica, our modeled LIG grounded ice extent closely resembles its present-day configuration, with no substantial grounding line retreat apparently in either the WSB, the Aurora Basin, or the Recovery catchment (Figure 1c).

Closer investigation of the Amundsen Sea Embayment reveals that the retreating grounding line in this area migrates inland of its present-day position shortly after $130 \mathrm{ka} \mathrm{BP}$ and progressively evacuates the interior of WAIS over the subsequent 3-4 kyr (Figure 2). This is consistent with the timing of WAIS retreat inferred 


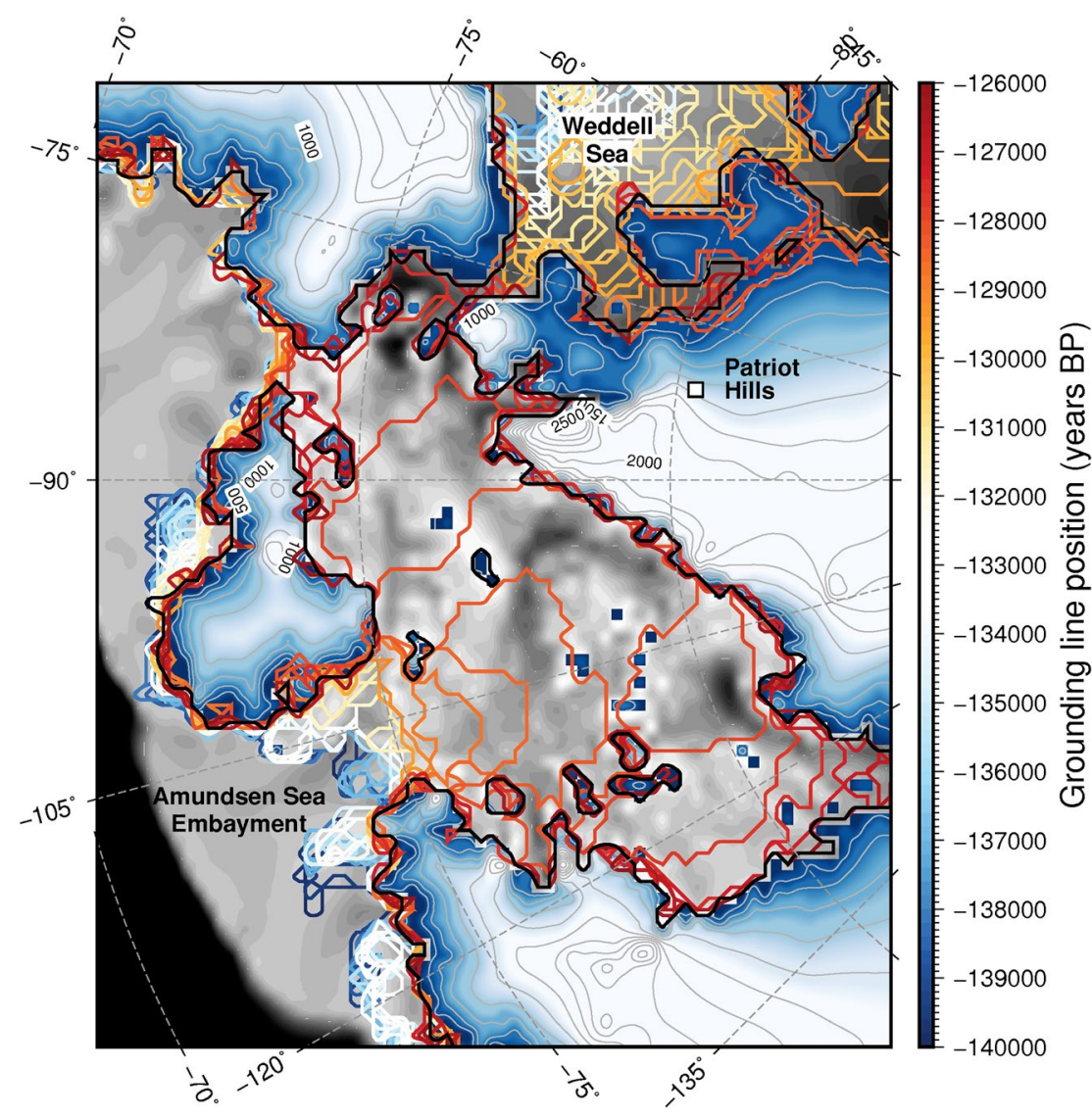

Figure 2. Grounding line retreat in the Amundsen Sea Embayment from 140 to 126 ka BP. Retreat proceeds rapidly into the interior of WAIS once the pinning point near the present-day grounding line is lost. Grounding line retreat in the Weddell Sea is slower, but takes place earlier. Blue-to-white shading and labeled contour lines show ice elevation; colored lines denote the modeled age of the grounding line position. Location of Patriot Hills ice core record (Turney, Fogwill, et al., 2020) also shown.

from marine sediments at ODP 1096 (Carlson et al., 2021), if uncertainties associated with the bounding tephra age (130.7 $\pm 1.8 \mathrm{ka}$; Hillenbrand et al., 2008) are considered. Grounded ice in the Weddell Sea embayment appears to retreat to close to its present-day extent in the millennia just before and just after $130 \mathrm{ka}$, and then stabilizes. Comparison of modeled grounding-line positions in the Weddell and Amundsen Sea sectors highlights the far more rapid retreat in the latter, consistent with previous interpretations of LIG marine ice sheet instability in this sector (Clark et al., 2020). The more rapid retreat we simulate than modeled previously (Figure 1b) arises from our stiffer mantle parameterization (see Section 2, above), leading to slower isostatic rebound that gives rise to deeper water during WAIS retreat.

To gauge the degree of fit between our simulation and two empirical studies that report isotopic evidence of changes in the AIS during the LIG, we first consider the isotope record recovered from the Blue Ice Area (BIA) of Horseshoe Valley, in the Patriot Hills of West Antarctica $\left(278.65^{\circ} \mathrm{E}, 80.3^{\circ} \mathrm{S}\right.$; Figures $1 \mathrm{c}$ and 2; Turney, Fogwill, et al., 2020). Although our $20 \mathrm{~km}$ resolution simulation is unable to simulate the detailed pattern of ice flow in the 30-km-wide Horseshoe Valley, our previous work has shown that behavior of this glacier is controlled to a large degree by activity of the Institute Ice Stream and regional ice flow patterns spanning length scales on the order of hundreds of kilometers (Fogwill et al., 2014; Turney, Fogwill, et al., 2020; Winter et al., 2016). The BIA horizontal core preserves tephra that is geochemically correlated to the Dome Fuji ice core, thereby stratigraphically linking East and West AISs. Stratigraphically above this horizon is a disconformity, representing an interval from 130 to $80 \mathrm{ka}$ when ice layers are absent. These missing layers could imply either a hiatus in accumulation, or post-depositional loss. Our simulation predicts a 5,000-year long episode of regional-scale ice thinning that coincides with the timing of tephra deposition 
and the beginning of the isotopic hiatus (Figure 3a). If this thinning had been driven by surface ablation (wind-induced sublimation) the tephra would not be preserved in situ. Conversely, if thinning were instead primarily the result of melting at the bed rather than at the surface, then the younger ice overlying the tephra should still be preserved, yet this is not the case.

In our simulation, the onset of thinning appears to be a response to a steady increase in surface velocity that started around $132.5 \mathrm{ka}$ (Figure 3b, red line). This date corresponds to the timing of southward retreat of the ice sheet grounding line in the Weddell Sea (Figure 2) that triggered regional uplift at the BIA site from ca. $131 \mathrm{ka}$ BP (Figure 3b, blue line). Combined with the collapse of the ASE glaciers from $129 \mathrm{ka}$ (Figure 2), the reduction in regional ice loading led to accelerated bedrock rebound and promoted faster basal sliding due to the increase in topographic gradient (Figure 3b, black line).

Since modeled surface velocities are an order of magnitude greater than the rate of basal sliding, flow must have occurred primarily by shear (internal deformation). Under this kind of flow regime, the increasing surface slope and surface velocity driven by Weddell Sea grounding line retreat and bedrock uplift would have led to faster flow and extensional thinning near the surface compared to in deeper ice layers. Thinning rates increased gradually from $132.5 \mathrm{ka}$ BP reaching a maximum of around $0.5 \mathrm{~m} /$ year by ca. $128.5 \mathrm{ka} \mathrm{BP}$ (Figure 3a). Snow layers accumulating during this time would have thus become increasingly thinned, relative to older layers beneath, as they flowed from their original location to the BIA sample site downstream. In this scenario, the apparent hiatus actually may represent a period of enhanced layer thinning that allowed stratigraphically separated isochrones to eventually intersect (Figure 3c). Although our simulations do not extend to $80 \mathrm{ka} \mathrm{BP}$, we surmise that thinning halted at $80 \mathrm{ka}$ because of renewed isostatic loading due to ASE regrowth, and/or because of readvancing of Weddell Sea grounding lines as the climate cooled. We caution, however, that our conceptual interpretation of this apparent hiatus is just one of many possibilities, and a more detailed study using a more highly vertically resolved ISM could be used to test this. To put the Patriot Hills record in context, we extracted modeled changes in ice sheet thickness and elevation at 15 other west and east Antarctic ice core sites (Figures 1c and S6). Whilst the East Antarctic locations (Dome C, Vostok, Dome F, EDML, Law Dome, TALDICE, and Taylor Dome) and Berkner Island and Mt Moulton sites in West Antarctica exhibit only minor modeled deviations from present, more substantial changes (hundreds of meters) are seen at RICE, Siple Dome, Patriot Hills, Skytrain, and Fletcher Promontory. Our model predicts complete ice sheet loss at the WAIS Divide and Byrd ice core locations in West Antarctica, as a consequence of westward ice divide and grounding line migration (Figure 1c). Furthermore, our model also allows us to predict where surface elevation changes may be explained partially or wholly by bedrock uplift associated with regional ice loss, which could help more accurately interpret isotopic changes from ice core records (Figure S6).

Many studies have considered the possibility that the WSB in East Antarctica could have collapsed during warmer periods of the past (Bertram et al., 2018; Cook et al., 2013; Golledge, Levy, et al., 2017; Mengel \& Levermann, 2014; Patterson et al., 2014), but to date, there is no evidence that unequivocally proves ice loss from this sector of the ice sheet. In lieu of glaciological evidence, we use geological records of sediment provenance changes from marine sediment core U1361A at $143.89^{\circ} \mathrm{E}, 64.41^{\circ} \mathrm{S}$ (Wilson et al., 2018). This archive preserves IBRD, as well as laminated clays whose barium/aluminum ratio indicates changes in sea ice extent and biological productivity. Co-variance of these markers with evidence of inland glacial erosion from geochemical provenance studies (Nd isotopes) has been used to suggest that reduced sea ice during Pleistocene interglacials was coincident with increased sediment erosion from the WSB, perhaps because of retreat of the ice margin (Wilson et al., 2018; Figure 4d). Inland terrestrial geochemical records, however, suggest that the WSB has been ice-filled since c. 400 ka BP (Blackburn et al., 2020), and hence if it did contribute to higher-than-present LIG GMSL, the contribution may have been relatively minor. Recent high-resolution ice sheet modeling as well as GCM experiments support this latter interpretation, showing that the isotopic record preserved in the Talos Dome ice core is inconsistent with the surface lowering of that area that would have occurred had the WSB deglaciated substantially (Goursaud et al., 2020; Sutter et al., 2020). Sutter et al. (2020) conclude that during the LIG the WSB could have contributed only up to ca. $0.8 \mathrm{~m}$ SLE.

Here we unify these studies. Figure 4a shows our modeled ice surface elevation over the WSB during the LIG at $126 \mathrm{ka}$ BP when modeled Antarctic ice loss peaked. Figure 4c shows modeled surface elevation 


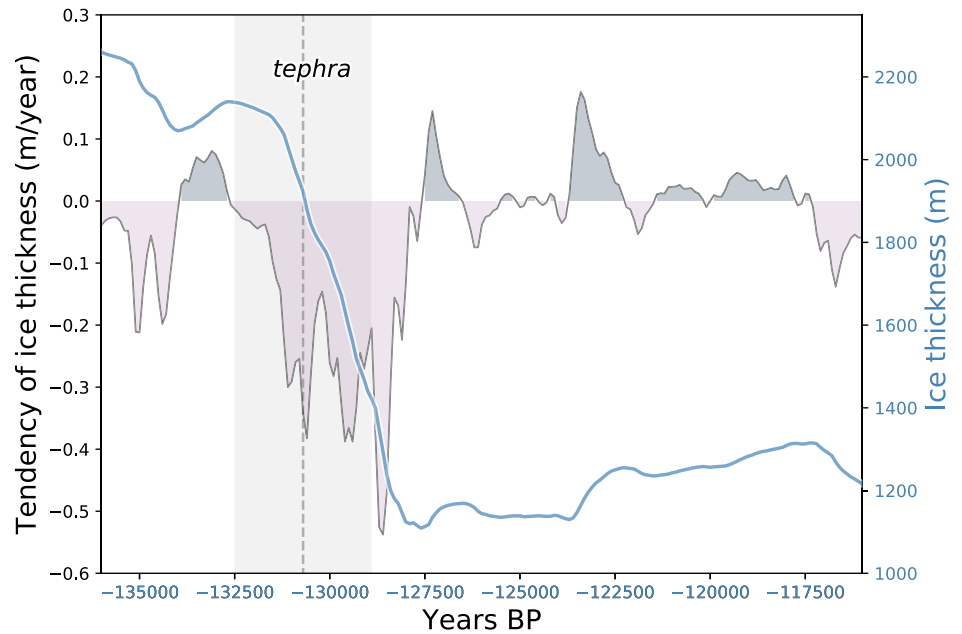

b

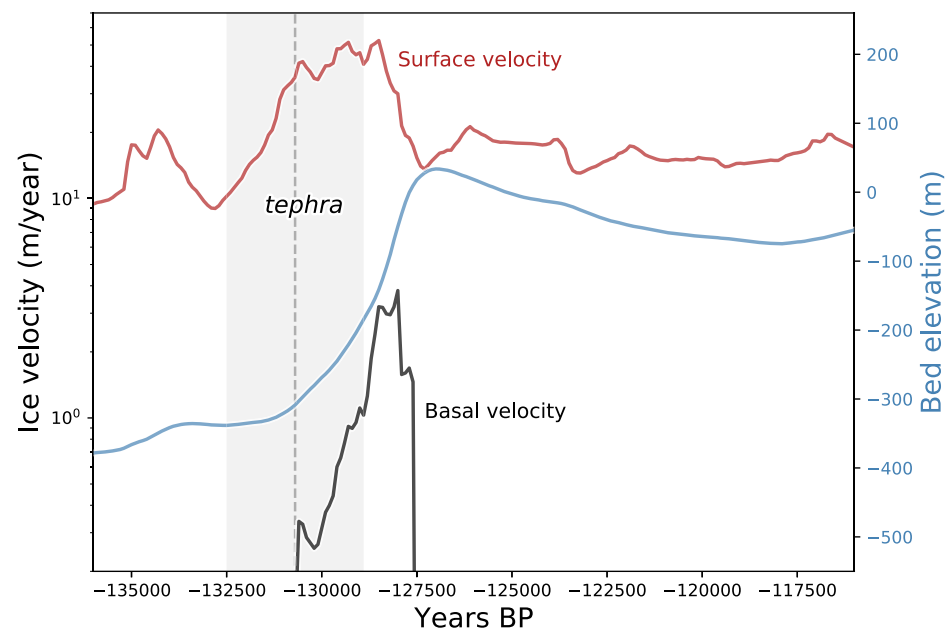

C

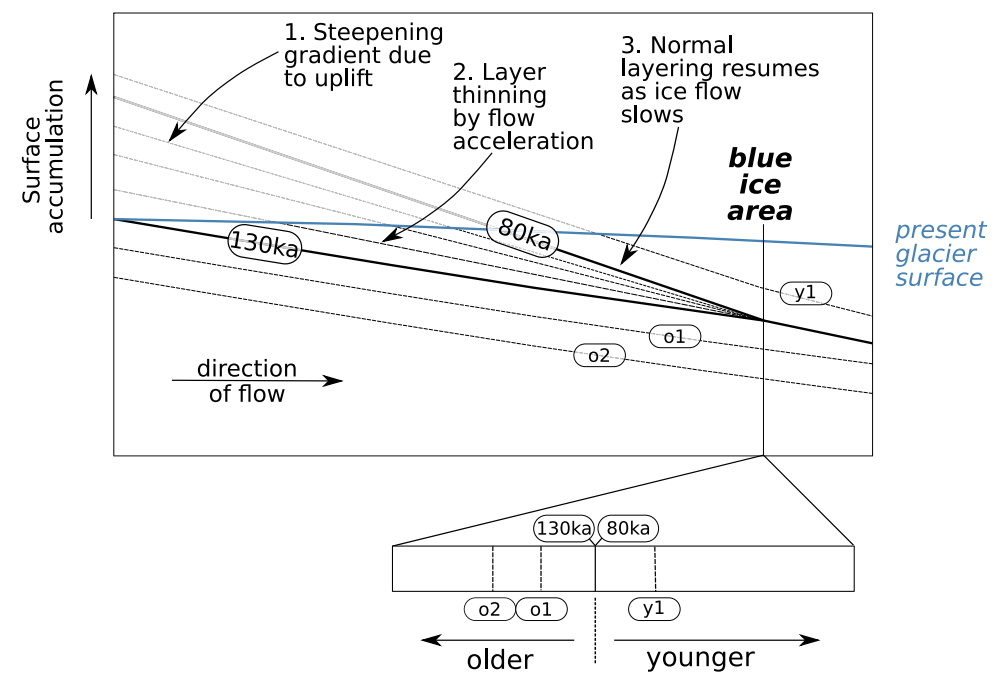

Figure 3. (a) Modeled ice thickness and its rate of change, and (b) bed elevation, and surface and basal velocity at the Patriot Hills blue ice area through the period 132-116 ka BP. Timing of tephra horizon marking the beginning of the hiatus in the core (Turney, Fogwill, et al., 2020) also shown (dotted line), including age uncertainty (gray shading). (c) Schematic explanation of the mechanism leading to the (c) 130-80 ka BP hiatus in the Patriot Hills ice core record. Steepening of the ice surface due to bedrock uplift and grounding-line retreat lead to enhancing thinning as ice is advected more quickly downglacier, eventually allowing time-separated ice layers (isochrones) to converge. 
a

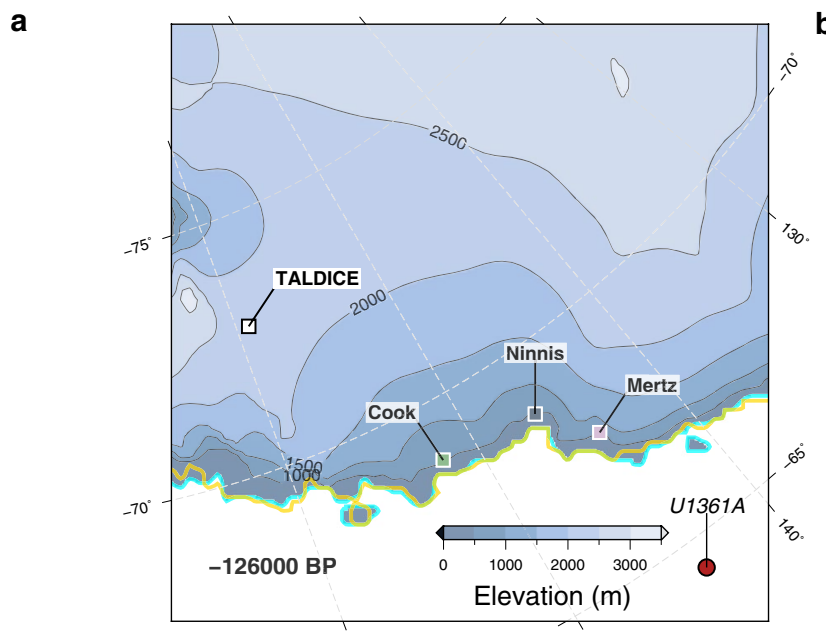

c

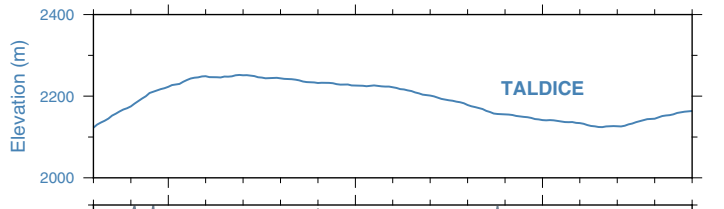

e

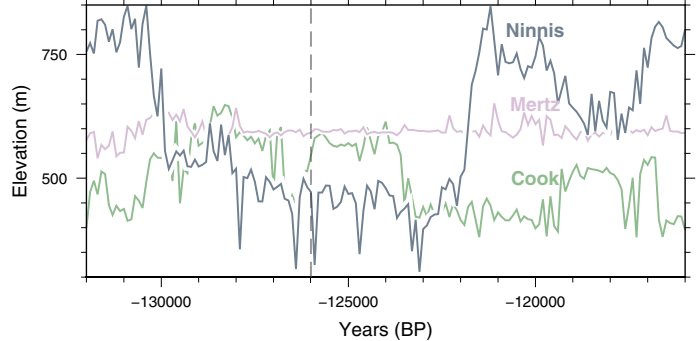

b

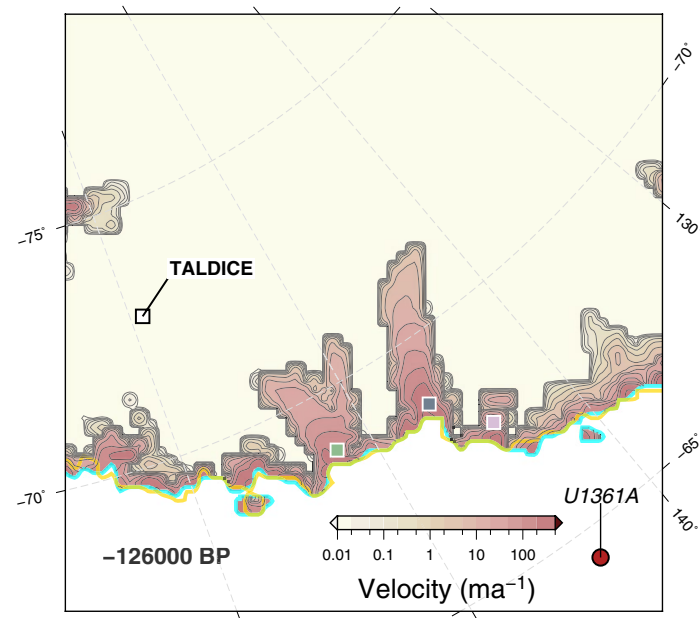

d

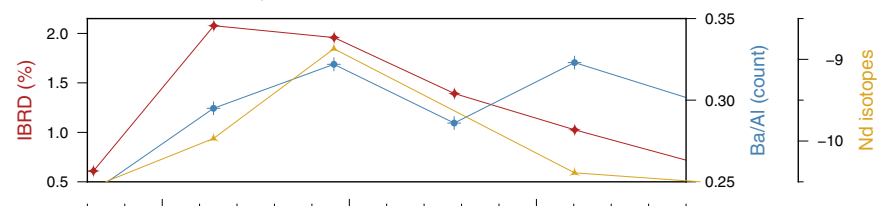

f

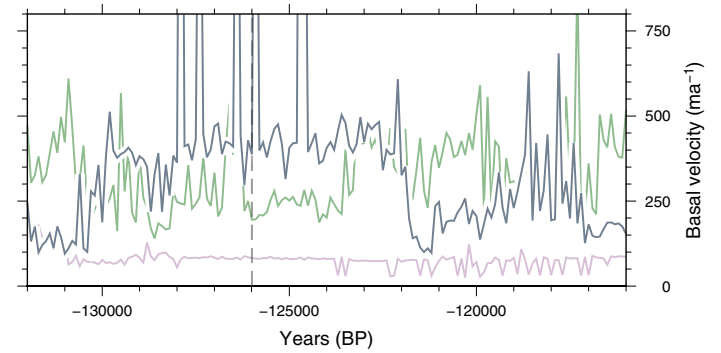

Figure 4. Ice thickness and basal ice velocity changes in the Wilkes Subglacial Basin during the period 132-116 ka BP. (a) Modeled ice elevation and (b) basal ice velocity at $126 \mathrm{ka}$ BP showing the location of the three main outlet glaciers in this region. Location of the Talos Dome ice core site (TALDICE) and marine sediment core U1361A also shown. Gold and cyan lines shows present-day and 126 ka BP grounding-line positions respectively. (c) Time series of modeled ice elevation changes and (d) sediment proxies from U1361A compared to (e) modeled elevation and (f) basal velocity changes at the three glacier trunks shown in (a). The model predicts substantial thinning and acceleration of Ninnis Glacier coincident with increased sediment flux to U1361A, yet without impact on ice thickness at Talos Dome. Vertical dotted lines identify the timeslice shown in panels (a) and (b).

change at Talos Dome from 132 to $116 \mathrm{ka}$ (blue line), and indicates changes of approximately $100 \mathrm{~m}$ over 10,000 years, consistent with the TALDICE reconstruction (Sutter et al., 2020). We also track changes in ice elevation and basal ice velocity in the key outlet glaciers of this region: Cook, Ninnis, and Mertz (Figures 4e and 4f). In contrast to the large-scale retreat in the ASE shown in Figure 2, our model predicts a stable margin in the WSB sector. Based on previous experimentation in which we explored the environmental sensitivity of each Antarctic catchment in detail (Golledge, Levy, et al., 2017) we conclude that the WSB remained stable during the LIG due to insufficient atmospheric warming that would have been needed to thin the ice sheet enough to render it vulnerable to ocean thermal forcing and grounding line retreat. Even in the absence of grounding-line retreat in this area, however, we simulate thinning of up to $500 \mathrm{~m}$ in the trunk of the Ninnis Glacier, coupled with an abrupt increase in sliding velocity from approximately 150 to $450 \mathrm{~m} /$ year. Because these accelerations are localized, however, the sea-level equivalent volume of this catchment is only $0.05 \mathrm{~m}$ less than in our modeled present-day geometry. Our modeled ice dynamic changes are coeval with the IBRD, Ba/Al, and Nd-based interpretations of ice sheet change shown in Figures 4d-4f. Since sliding velocity controls basal erosion and subglacial sediment transport (Herman et al., 2015; Pollard \& DeConto, 2003), our modeled ice flow acceleration can plausibly explain the increased inland basal erosion inferred from marine sediment core U1361A (Wilson et al., 2018). 


\section{Implications for Future Change}

Our new simulation, using a stiffer mantle compared to our previous experiments (Clark et al., 2020), produces a simulated LIG AIS evolution that is temporally and spatially consistent with Antarctic marine sediment records, with glaciological records of ice thickness change, and with probabilistic assessments of global mean sea level. Using this empirically constrained model, we are also able to make inferences regarding future AIS evolution. In particular, one notable feature of our T1 tuning experiment (Figure 1a) is that after a period of relative stability during the Holocene (approximately the last 10,000 years), our model predicts renewed, and rapid, AIS mass loss beginning c. 1,500 years after the present-day. The trajectory of ice loss over the period 1,500-4,000 years into the future is similar to the pattern of loss taking place during the early millennia of the LIG (Figure 1b), reflecting MISI-forced collapse of the ASE sector of WAIS. Given that no additional environmental forcing is applied during this period (from year 0 into the future), the lagged response is most likely a consequence of our basal melt parameterization, which is optimized to closely reproduce present-day (1979-2010) melt rates (Bernales et al., 2017; Golledge et al., 2019). The implication therefore is that ocean warming to date is already sufficient to trigger millennial-scale collapse of part of West Antarctica, as has been found previously (Arthern \& Williams, 2017; Garbe et al., 2020; Golledge et al., 2019; Joughin et al., 2014).

\section{Data Availability Statement}

Ice sheet model outputs shown in this study are available at the Open Science Framework (https://doi. org/10.17605/OSF.IO/GZB3H). Climate model outputs used are available at https://doi.org/10.17605/OSF. IO/FX7WK.

\section{Acknowledgments}

NRG acknowledges funding from Royal Society of New Zealand contract VUW1501. Simulations on which this work is based were funded by US National Science Foundation (NSF) through grant numbers AGS-1503032 (to PUC and AEC), AGS-1502990 (to FH), 1559040 (to AD), and OPP-1443437 (to AEC).

FH gratefully acknowledges the NOAA Climate and Global Change Postdoctoral Fellowship program, administered by the University Corporation for Atmospheric Research. High-performance computing support from Yellowstone (http://n2t.net/ark:/85065/ d7wd3xhc) and Cheyenne (http:// www.doi.org/10.5065/D6RX99HX) was provided by NCAR's Computational and Information Systems Laboratory, sponsored by the NSF. This research used resources of the Oak Ridge Leadership Computing Facility at the Oak Ridge National Laboratory, which is supported by the Office of Science of the US Department of Energy under contract number DE-AC05-00OR22725. AD gratefully acknowledges the U.S. Fulbright Scholar Program. CSMT and CJF acknowledge support from the Australian Research Council (ARC), including Linkage Project (LP120200724) and Discovery Project DP210103621, supported by Antarctic Logistics and Expeditions. NRG, TRN, RHL, RMM, DPL, NANB, and GBD acknowledge support from Ministry for Business, Innovation and Employment contracts RTUV1705 (NZSeaRise) and ANTA1801 (Antarctic Science Platform). PISM is supported by NASA grant numbers NNX13AM16G and NNX13AK27G.

\section{Conflict of Interest}

The authors declare no conflicts of interest relevant to this study.

\section{References}

Arthern, R. J., \& Williams, C. R. (2017). The sensitivity of West Antarctica to the submarine melting feedback. Geophysical Research Letters, 44(5), 2352-2359. https://doi.org/10.1002/2017gl072514

Austermann, J., Pollard, D., Mitrovica, J. X., Moucha, R., Forte, A. M., DeConto, R. M., et al. (2015). The impact of dynamic topography change on Antarctic ice sheet stability during the mid-Pliocene warm period. Geology, 43(10), 927-930. https://doi.org/10.1130/g36988.1

Bernales, J., Rogozhina, I., \& Thomas, M. (2017). Melting and freezing under Antarctic ice shelves from a combination of ice-sheet modelling and observations. Journal of Glaciology, 63, 731-744. https://doi.org/10.1017/jog.2017.42

Bertram, R. A., Wilson, D. J., van de Flierdt, T., McKay, R. M., Patterson, M. O., Jimenez-Espejo, F. J., et al. (2018). Pliocene deglacial event timelines and the biogeochemical response offshore Wilkes Subglacial Basin, East Antarctica. Earth and Planetary Science Letters, 494, 109-116. https://doi.org/10.1016/j.epsl.2018.04.054

Blackburn, T., Edwards, G. H., Tulaczyk, S., Scudder, M., Piccione, G., Hallet, B., et al. (2020). Ice retreat in Wilkes Basin of East Antarctica during a warm interglacial. Nature, 583, 554-559. https://doi.org/10.1038/s41586-020-2484-5

Bradley, S. L., Hindmarsh, R. C. A., Whitehouse, P. L., Bentley, M. J., \& King, M. A. (2015). Low post-glacial rebound rates in the Weddell sea due to late Holocene ice-sheet readvance. Earth and Planetary Science Letters, 413, 79-89. https://doi.org/10.1016/j.epsl.2014.12.039

Bradley, S. L., Reerink, T. J., Van De Wal, R. S., \& Helsen, M. M. (2018). Simulation of the Greenland Ice Sheet over two glacial-interglacial cycles: Investigating a sub-ice-shelf melt parameterization and relative sea level forcing in an ice-sheet-ice-shelf model. Climate of the Past, 14(5), 619-635. https://doi.org/10.5194/cp-14-619-2018

Bueler, E., \& Brown, J. (2009). Shallow shelf approximation as a "sliding law" in a thermomechanically coupled ice sheet model. Journal of Geophysical Research, 114, F03008. https://doi.org/10.1029/2008jf001179

Bueler, E., Lingle, C., \& Brown, J. (2007). Fast computation of a viscoelastic deformable Earth model for ice-sheet simulations. Annals of Glaciology, 46, 97-105. https://doi.org/10.3189/172756407782871567

Calov, R., Robinson, A., Perrette, M., \& Ganopolski, A. (2015). Simulating the Greenland ice sheet under present-day and palaeo constraints including a new discharge parameterization. The Cryosphere, 9, 179-196. https://doi.org/10.5194/tc-9-179-2015

Carlson, A. E., Beard, B. L., Hatfield, R. G., \& Laffin, M. (2021). Absence of West Antarctic-sourced silt at ODP Site 1096 in the Bellingshausen Sea during the last interglaciation: Support for West Antarctic ice-sheet deglaciation. Quaternary Science Reviews, 261, 106939. https://doi.org/10.1016/j.quascirev.2021.106939

Chadwick, M., Allen, C., Sime, L., \& Hillenbrand, C.-D. (2020). Analysing the timing of peak warming and minimum winter sea-ice extent in the Southern Ocean during MIS 5e. Quaternary Science Reviews, 229, 106134. https://doi.org/10.1016/j.quascirev.2019.106134

Clark, P. U., He, F., Golledge, N. R., Mitrovica, J. X., Dutton, A., Hoffman, J. S., \& Dendy, S. (2020). Oceanic forcing of penultimate deglacial and last interglacial sea-level rise. Nature, 577, 660-664. https://doi.org/10.1038/s41586-020-1931-7

Colville, E. J., Carlson, A. E., Beard, B. L., Hatfield, R. G., Stoner, J. S., Reyes, A. V., \& Ullman, D. J. (2011). Sr-Nd-Pb isotope evidence for ice-sheet presence on Southern Greenland during the Last Interglacial. Science, 333, 620-623. https://doi.org/10.1126/science.1204673

Cook, C. P., van de Flierdt, T., Williams, T., Hemming, S. R., Iwai, M., Kobayashi, M., et al. (2013). Dynamic behaviour of the East Antarctic ice sheet during Pliocene warmth. Nature Geoscience, 6(9), 765-769. https://doi.org/10.1038/ngeo1889 
Dahl-Jensen, D., Albert, M., Aldahan, A., Azuma, N., Balslev-Clausen, D., \& Baumgartner, M. (2013). Eemian interglacial reconstructed from a Greenland folded ice core. Nature, 493(7433), 489-494. https://doi.org/10.1038/nature11789

DeConto, R., \& Pollard, D. (2016). Contribution of Antarctica to past and future sea-level rise. Nature, 531, 591-597. https://doi.org/10.1038/ nature 17145

Dutton, A., Carlson, A., Long, A., Milne, G., Clark, P., DeConto, R., et al. (2015). Sea-level rise due to polar ice-sheet mass loss during past warm periods. Science, 349, aaa4019. https://doi.org/10.1126/science.aaa4019

Feldmann, J., \& Levermann, A. (2015). Interaction of marine ice-sheet instabilities in two drainage basins: Simple scaling of geometry and transition time. The Cryosphere, 9, 631-645. https://doi.org/10.5194/tc-9-631-2015

Fischer, H., Meissner, K. J., Mix, A. C., Abram, N. J., Austermann, J., Brovkin, V., et al. (2018). Palaeoclimate constraints on the impact of $2^{\circ} \mathrm{C}$ anthropogenic warming and beyond. Nature Geoscience, 11(7), 474-485. https://doi.org/10.1038/s41561-018-0146-0

Fogwill, C., Turney, C., Golledge, N., Rood, D., Hippe, K., Wacker, L., et al. (2014). Drivers of abrupt Holocene shifts in West Antarctic ice stream direction determined from combined ice sheet modelling and geologic signatures. Antarctic Science, 26(6), 674-686. https://doi. $\operatorname{org} / 10.1017 / \mathrm{s} 0954102014000613$

Garbe, J., Albrecht, T., Levermann, A., Donges, J. F., \& Winkelmann, R. (2020). The hysteresis of the Antarctic ice sheet. Nature, 585(7826), 538-544. https://doi.org/10.1038/s41586-020-2727-5

Goelzer, H., Huybrechts, P., Loutre, M.-F., \& Fichefet, T. (2016). Last Interglacial climate and sea-level evolution from a coupled ice sheetclimate model. Climate of the Past, 12(12), 2195-2213. https://doi.org/10.5194/cp-12-2195-2016

Golledge, N. R., Keller, E. D., Gomez, N., Naughten, K. A., Bernales, J., Trusel, L. D., \& Edwards, T. L. (2019). Global environmental consequences of twenty-first-century ice-sheet melt. Nature, 566, 65-72. https://doi.org/10.1038/s41586-019-0889-9

Golledge, N. R., Levy, R. H., McKay, R. M., \& Naish, T. R. (2017). East Antarctic ice sheet most vulnerable to Weddell Sea warming. Geophysical Research Letters, 44, 2343-2351. https://doi.org/10.1002/2016gl072422

Golledge, N. R., Thomas, Z., Levy, R., Gasson, E., Naish, T., McKay, R., et al. (2017). Antarctic climate and ice sheet configuration during a peak-warmth Early Pliocene interglacial. Climate of the Past, 13, 959-975. https://doi.org/10.5194/cp-13-959-2017

Goursaud, S., Holloway, M., Sime, L., Wolff, E., Valdes, P., Steig, E. J., \& Pauling, A. (2020). Antarctic Ice Sheet elevation impacts on water isotope records during the Last Interglacial. Geophysical Research Letters, 48, e2020GL091412. https://doi.org/10.1029/2020GL091412

Herman, F., Beyssac, O., Brughelli, M., Lane, S. N., Leprince, S., Adatte, T., et al. (2015). Erosion by an Alpine glacier. Science, 350(6257), 193-195. https://doi.org/10.1126/science.aab2386

Hillenbrand, C.-D., Moreton, S., Caburlotto, A., Pudsey, C., Lucchi, R., Smellie, J., \& Larter, R. (2008). Volcanic time-markers for Marine Isotopic Stages 6 and 5 in Southern Ocean sediments and Antarctic ice cores: Implications for tephra correlations between palaeoclimatic records. Quaternary Science Reviews, 27(5-6), 518-540. https://doi.org/10.1016/j.quascirev.2007.11.009

Hoffman, J. S., Clark, P. U., Parnell, A. C., \& He, F. (2017). Regional and global sea-surface temperatures during the last interglaciation. Science, 355(6322), 276-279. https://doi.org/10.1126/science.aai8464

Holloway, M. D., Sime, L. C., Singarayer, J. S., Tindall, J. C., Bunch, P., \& Valdes, P. J. (2016). Antarctic last interglacial isotope peak in response to sea ice retreat not ice-sheet collapse. Nature Communications, 7(1), 1-9. https://doi.org/10.1038/ncomms12293

Huybrechts, P. (2002). Sea-level changes at the LGM from ice-dynamic reconstructions of the Greenland and Antarctic ice sheets during the glacial cycles. Quaternary Science Reviews, 21(1-3), 203-231. https://doi.org/10.1016/s0277-3791(01)00082-8

Huybrechts, P., \& De Wolde, J. (1999). The dynamic response of the Greenland and Antarctic ice sheets to multiple-century climatic warming. Journal of Climate, 12(8), 2169-2188. https://doi.org/10.1175/1520-0442(1999)012<2169:tdrotg>2.0.co;2

Ivins, E., van der Wal, W., Wiens, D., Lloyd, A., \& Caron, L. (2021). Antarctic mantle rheology. London, UK: Geological Society of London.

Joughin, I., Smith, B. E., \& Medley, B. (2014). Marine Ice Sheet collapse potentially under way for the Thwaites Glacier Basin, West Antarctica. Science, 344, 735-738. https://doi.org/10.1126/science.1249055

Kopp, R. E., Simons, F. J., Mitrovica, J. X., Maloof, A. C., \& Oppenheimer, M. (2009). Probabilistic assessment of sea level during the last interglacial stage. Nature, 462(7275), 863-867. https://doi.org/10.1038/nature08686

Landais, A., Masson-Delmotte, V., Capron, E., Langebroek, P. M., Bakker, P., Stone, E. J., et al. (2016). How warm was Greenland during the last interglacial period? Climate of the Past, 12(9), 1933-1948. https://doi.org/10.5194/cp-12-1933-2016

Lingle, C., \& Clark, J. (1985). A numerical model of interactions between a marine ice sheet and the solid earth: Application to a West Antarctic ice stream. Journal of Geophysical Research, 90, 1100-1114. https://doi.org/10.1029/jc090ic01p01100

Marino, G., Rohling, E., Rodriguez-Sanz, L., Grant, K., Heslop, D., Roberts, A., et al. (2015). Bipolar seesaw control on last interglacial sea level. Nature, 522, 197-201. https://doi.org/10.1038/nature14499

Marzeion, B., Hock, R., Anderson, B., Bliss, A., Champollion, N., \& Fujita, K. (2020). Partitioning the uncertainty of ensemble projections of global glacier mass change. Earth's Future, 8(7), e2019EF001470. https://doi.org/10.1029/2019EF001470

Masson-Delmotte, V., Schulz, M., Abe-Ouchi, A., Beer, J., Ganopolski, A., González Rouco, J., et al. (Eds.). (2013). Information from paleoclimate archives. In Climate change 2013: The physical science basis. Contribution of working group I to the fifth assessment report of the intergovernmental panel on climate change (pp. 383-464).

Mengel, M., \& Levermann, A. (2014). Ice plug prevents irreversible discharge from East Antarctica. Nature Climate Change, 4, 451-455. https://doi.org/10.1038/nclimate2226

Nield, G. A., Whitehouse, P. L., King, M. A., \& Clarke, P. J. (2016). Glacial isostatic adjustment in response to changing Late Holocene behaviour of ice streams on the Siple Coast, West Antarctica. Geophysical Supplements to the Monthly Notices of the Royal Astronomical Society, 205(1), 1-21. https://doi.org/10.1093/gji/ggv532

Pan, L., Powell, E. M., Latychev, K., Mitrovica, J. X., Creveling, J. R., Gomez, N., \& Clark, P. U. (2021). Rapid postglacial rebound amplifies global sea level rise following West Antarctic Ice Sheet collapse. Science Advances, eabf7787. 1-9. https://doi.org/10.1126/sciadv.abf7787

Patterson, M., McKay, R., Naish, T., Escutia, C., Jimenez-Espejo, F., Raymo, M., et al. (2014). Orbital forcing of the East Antarctic ice sheet during the Pliocene and Early Pleistocene. Nature Geoscience, 7, 841-847. https://doi.org/10.1038/ngeo2273

Pollard, D., \& DeConto, R. M. (2003). Antarctic ice and sediment flux in the Oligocene simulated by a climate-ice sheet-sediment model. Palaeogeography, Palaeoclimatology, Palaeoecology, 198, 53-67. https://doi.org/10.1016/s0031-0182(03)00394-8

Rohling, E. J., Hibbert, F. D., Grant, K. M., Galaasen, E. V., Irvalı, N., \& Kleiven, H. F. (2019). Asynchronous Antarctic and Greenland ice-volume contributions to the last interglacial sea-level highstand. Nature Communications, 10(1), 1-9. https://doi.org/10.1038/ s41467-019-12874-3

Samrat, N. H., King, M. A., Watson, C., Hooper, A., Chen, X., Barletta, V. R., \& Bordoni, A. (2020). Reduced ice mass loss and three-dimensional viscoelastic deformation in northern Antarctic Peninsula inferred from GPS. Geophysical Journal International, 222(2), 1013-1022. https://doi.org/10.1093/gji/ggaa229 
Shackleton, S., Baggenstos, D., Menking, J., Dyonisius, M., Bereiter, B., Bauska, T., et al. (2020). Global ocean heat content in the Last Interglacial. Nature Geoscience, 13(1), 77-81. https://doi.org/10.1038/s41561-019-0498-0

Steig, E. J., Huybers, K., Singh, H. A., Steiger, N. J., Ding, Q., Frierson, D. M., et al. (2015). Influence of West Antarctic ice sheet collapse on Antarctic surface climate. Geophysical Research Letters, 42(12), 4862-4868. https://doi.org/10.1002/2015gl063861

Sutter, J., Eisen, O., Werner, M., Grosfeld, K., Kleiner, T., \& Fischer, H. (2020). Limited retreat of the Wilkes Basin ice sheet during the Last Interglacial. Geophysical Research Letters, 47(13), e2020GL088131. https://doi.org/10.1029/2020gl088131

Turney, C., Fogwill, C., Golledge, N., McKay, N. P., van Sebille, E., Jones, R. T., et al. (2020). Early Last Interglacial ocean warming drove substantial ice mass loss from Antarctica. Proceedings of the National Academy of Sciences of the United States of America, 117(8), 3996-4006. https://doi.org/10.1073/pnas.1902469117

Turney, C., Jones, R., McKay, N., Van Sebille, E., Thomas, Z., Hillenbrand, C.-D., \& Fogwill, C. (2020). A global mean sea surface temperature dataset for the Last Interglacial (129-116 ka) and contribution of thermal expansion to sea level change. Earth System Science Data, 12(4), 3341-3356. https://doi.org/10.5194/essd-12-3341-2020

Wilson, D. J., Bertram, R. A., Needham, E. F., van de Flierdt, T., Welsh, K. J., McKay, R. M., et al. (2018). Ice loss from the East Antarctic Ice Sheet during late Pleistocene interglacials. Nature, 561(7723), 383-386. https://doi.org/10.1038/s41586-018-0501-8

Winkelmann, R., Martin, M. A., Haseloff, M., Albrecht, T., Bueler, E., Khroulev, C., \& Levermann, A. (2010). The Potsdam Parallel Ice Sheet Model (PISM-PIK) - Part 1: Model description. The Cryosphere, 5, 715-726.

Winter, K., Woodward, J., Dunning, S. A., Turney, C. S., Fogwill, C. J., Hein, A. S., et al. (2016). Assessing the continuity of the blue ice climate record at Patriot Hills, Horseshoe Valley, West Antarctica. Geophysical Research Letters, 43(5), 2019-2026. https://doi. org/10.1002/2015gl066476

Wolstencroft, M., King, M. A., Whitehouse, P. L., Bentley, M. J., Nield, G. A., King, E. C., et al. (2015). Uplift rates from a new high-density GPS network in Palmer Land indicate significant late Holocene ice loss in the southwestern Weddell Sea. Geophysical Journal International, 203(1), 737-754. https://doi.org/10.1093/gii/ggv327

Yau, A. M., Bender, M. L., Robinson, A., \& Brook, E. J. (2016). Reconstructing the last interglacial at Summit, Greenland: Insights from GISP2. Proceedings of the National Academy of Sciences of the United States of America, 113(35), 9710-9715. https://doi.org/10.1073/ pnas. 1524766113

Zwally, H. J., Giovinetto, M. B., Beckley, M. A., \& Saba, J. L. (2012). Antarctic and Greenland drainage systems. GSFC Cryospheric Sciences Laboratory. Retrieved from http://icesat4.gsfc.nasa.gov/cryo_data/ant_grn_drainage_systems.php

\section{References From the Supporting Information}

Menviel, L., Timmermann, A., Timm, O. E., \& Mouchet, A. (2010). Climate and biogeochemical response to a rapid melting of the West Antarctic Ice Sheet during interglacials and implications for future climate. Paleoceanography, 25, PA4231. https://doi. org/10.1029/2009pa001892

Powell, E., Gomez, N., Hay, C., Latychev, K., \& Mitrovica, J. (2020). Viscous effects in the solid Earth response to modern Antarctic ice mass flux: Implications for geodetic studies of WAIS stability in a warming world. Journal of Climate, 33(2), 443-459. https://doi.org/10.1175/ jcli-d-19-0479.1

Simms, A. R., Ivins, E. R., DeWitt, R., Kouremenos, P., \& Simkins, L. M. (2012). Timing of the most recent Neoglacial advance and retreat in the South Shetland Islands, Antarctic Peninsula: Insights from raised beaches and Holocene uplift rates. Quaternary Science Reviews, 47, 41-55. https://doi.org/10.1016/j.quascirev.2012.05.013

Zhao, C., King, M. A., Watson, C. S., Barletta, V. R., Bordoni, A., Dell, M., \& Whitehouse, P. L. (2017). Rapid ice unloading in the Fleming Glacier region, southern Antarctic Peninsula, and its effect on bedrock uplift rates. Earth and Planetary Science Letters, 473, 164-176. https://doi.org/10.1016/j.epsl.2017.06.002 